\title{
AN ASIAN ORCHID, EULOPHIA GRAMINEA (ORCHIDACEAE: CYMBIDIEAE), NATURALIZES IN FLORIDA
}

\author{
Robert W. Pemberton ${ }^{1,3}$, Timothy M. Collins ${ }^{2} \&$ Suzanne Koptur $^{2}$ \\ ${ }^{1}$ Fairchild Tropical Botanic Garden, 2121 SW 28 ${ }^{\text {th }}$ Terrace Ft. Lauderdale, Florida 33312 \\ ${ }^{2}$ Department of Biological Sciences, Florida International University, Miami, FL 33199 \\ ${ }^{3}$ Author for correspondence: Robert.Pemberton@ars.usda.gov
}

\begin{abstract}
Aвstract. Eulophia graminea, a terrestrial orchid native to Asia, has naturalized in southern Florida. Orchids naturalize less often than other flowering plants or ferns, but $E$. graminea has also recently become naturalized in Australia. Plants were found growing in five neighborhoods in Miami-Dade County, spanning $35 \mathrm{~km}$ from the most northern to the most southern site, and growing only in woodchip mulch at four of the sites. Plants at four sites bore flowers, and fruit were observed at two sites. Hand pollination treatments determined that the flowers are self compatible but fewer fruit were set in selfed flowers (4/10) than in out-crossed flowers (10/10). No fruit set occurred in plants isolated from pollinators, indicating that $E$. graminea is not autogamous. Pollinia removal was not detected at one site, but was $24.3 \%$ at the other site evaluated for reproductive success. A total of 26 and 92 fruit were found at these two sites, where an average of 6.5 and 3.4 fruit were produced per plant. These fruits ripened and dehisced rapidly; some dehiscing while their inflorescences still bore open flowers. Fruit set averaged 9.2 and $4.5 \%$ at the two sites. No floral visitors were seen during limited ( $6.5 \mathrm{hr}$ duration) timed watches of flowers. Individual flowers are open an average 11 days, and the inflorescences may bear flowers for at least one month. How E. graminea entered Florida is unknown, but capsules, bulbs and plantlets in flasks are available for sale and/or trade via the internet from Thailand and other places outside the U.S. The occurrence of the orchid at 900-1000 m elevation its native Sikkim $\left(27-28^{\circ} \mathrm{N}\right)$ and in Kashmir (above $32^{\circ} \mathrm{N}$ ), suggest that it can live well north of current area of naturalization in southern Florida, which is at sea level and $26^{\circ} \mathrm{N}$ latitude.
\end{abstract}

KEY wORDs: breeding system, Eulophia, orchid, mulch, naturalization, pollination

A terrestrial orchid, Eulophia graminea Lindl., native to subtropical and tropical Asia, has been detected in Miami-Dade County in southeastern Florida (Fig. 1-2). Its occurrence is noteworthy because relatively few orchids naturalize.

In the native region, Eulophia graminea occurs widely, from South Asia and Southeast Asia to eastern Asia to subtropical islands in the western Pacific. More specifically, it has been reported from Pakistan (Singapur), Kashmir, eastwards to Burma, Thailand, Malaysia, also Sri Lanka, Nikobar Isl., Philippines, Taiwan (Renz 1984). It also occurs in Singapore (Keng et al. 1989), the Himalayas (Nepal and Sikkim) from 900-1000 m (Singh 2001), Laos and Indonesia (GRIN 2008), China (Guangdong, Guangxi, Guizhou, Hainan, Yunnan; and Hong Kong) (http://mobot.mobot.org/W3T/Search/FOC/projsfoc. html), the Ryuku Islands (Japan) (Garay \& Sweet 1974) and Guam (GRIN 2008).

Within its native range Eulophia graminea occurs in diverse habitats. In Singapore it is reported to be common on wasteland, sandy beaches, lawns, roadsides and other exposed areas (Keng et al. 1998), as well as open areas in secondary forests and parks (Tan 1993). In Taiwan, the orchid grows among shrubs in lowlands, on beaches, coastal grassland ( $\mathrm{Su} 2000)$. In the Ryukus, it is uncommon in mountains and open low areas (Garay and Sweet 1974). The species is threatened in Sri Lanka (http://www.environmentlanka.com/biodiv/ iucn plant list.htm).

Eulophia graminea was discovered to be naturalized in Australia in the Northern Territories in 2001 (http://www.daff.gov.au/animal-planthealth/pests-diseases-weeds/weeds/incursion). In the 
Northern Territories the orchid is found in and around Darwin growing in woodchip mulched garden beds (Macrae 2002), and also "found pushing its way through bitumen and concrete" (Hussey \& Lloyd 2002). It has also recently reported from Queensland, Australia (Pier 2008).

This study was undertaken to define and better understand the orchid's occurrence, its reproduction, potential to persist and spread in Florida and beyond.

\section{Methods}

Identification - The identity of Eulophia graminea was confirmed with technical descriptions in Flora of Taiwan (Editorial Committee of the Flora of Taiwan, 1993, Flora of Pakistan (Renz 1984), and Flora of the Ryuku Islands (Garay \& Sweet 1974), and by Surangraj Indhamusika, of the Queen Sirikit Botanical Garden in Chiang Mai Thailand. To distinguish this orchid from related Florida orchids, published accounts of the morphological characteristics of Eulophia graminea and those orchids were compared. Herbarium specimens (Pemberton 07-01, 07-02, 08-01, 08-02, 08-03) have been placed in the herbaria of Fairchild Tropical Garden (FTG) in Coral Gables, the Florida Museum of Natural History (FLAS) in Gainesville, and the University of South Florida (USF) in Tampa.

Occurrence - After the orchid was first discovered in a residential garden in South Miami, its occurrence was determined by surveying the neighborhood to find plants and counting and describing the encountered plants. We interviewed people associated with yards where the plants were found to learn when the plants were first observed, and what other information they might have, pertaining to the possible origin of the orchids. We surveyed parks and mulched sites within a mile of the South Miami discovery site for additional plants. Interviews and discussions with colleagues led to the discovery of four additional sites with the orchid. Sites in western Kendall, Little River Miami, and North Miami were surveyed to confirm the occurrence and circumstance. Information about the eastern Kendall occurrence, including photographs of the plant and site, was provided by the reporting botanist Steve Woodmansee.
Breeding System and Pollination - Eulophia graminea plants and flowers were observed and manipulated to gain insights into the orchid's breeding system and pollination ecology. We examined flowers to detect rewards and inflorescences to discern odors. To assess male and female reproductive success, we measured fruit formation and pollinia removal in the South Miami and Little River Miami populations where multiple reproductive plants occurred. Pollinia removal was scored during single visits in October and November, 2007 in the South Miami population, and during one visit during April 2008 to the Little River Miami population. Fruit set in South Miami plants was determined by counting the number of fruit or fruit remnants, and the number of persistent bracts that subtended the flowers on old inflorescences on three plants during March, 2008, after the plants had flowered. Fruit set in the Little River Miami plants was determined by counting the number of fruit or fruit remnants, and the number of persistent bracts that subtended old or fallen flowers on 27 plants during April, 2008, near the end of flowering period for most of plants. Timed watches were made during October, November 2007, January and April 2008 to observe flower visitors. Flowers at the South Miami site were hand pollinated with self pollinia and crossed using pollinia from flowers of other plants at the same site and date to determine whether the plant is self compatible, and to compare self and outcross fruit set. Potted plants raised from bulbs dug at the South Miami site were placed inside a screen enclosure when their inflorescences appeared to determine the ability of the flowers to set fruit without pollinators, which would indicate either autogamous self pollination or apomixis. Selected flowers on these inflorescences were tagged as soon as they opened and followed until wilting to determine their longevity. Potted flowering plants were exposed in Ft. Lauderdale and Homestead gardens to increase observations of potential pollinators and to access the Eulophia graminea's ability to set fruit at other locations other than the South Miami and Little River Miami naturalization sites.

Possible Routes of Introduction - Internet searches were made to find evidence of the plant's cultivation, presence in commerce, or other human aided movement. The importation of commodities or other 


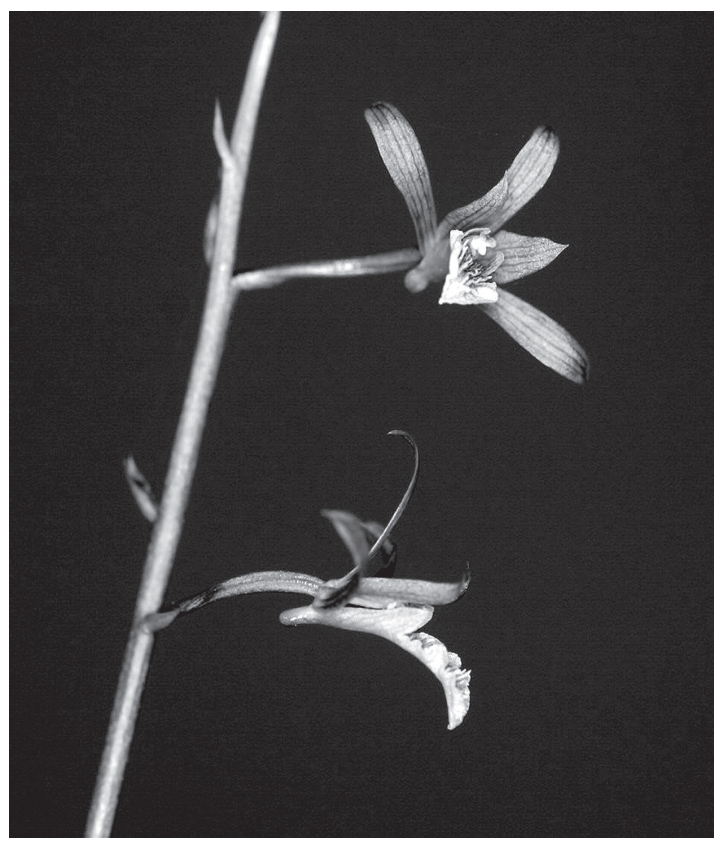

FIgURE 1. Eulophia graminea flowers (ca. $2.5 \mathrm{~cm}$ wide).

Note the nearly horizontal position of the lateral sepals and the nectar spur.

bulk materials that may have carried propagules (bulbs and/or seed) of the orchid from the native region to the U.S. was investigated by examining U.S. Department of Agriculture importation data posted on the Foreign Agriculture Service website.

\section{Results}

Description and distinguishing characteristics Plants terrestrial and autotrophic. Pseudobulbs ovoid with 4-5 concentric internodes, initially covered with many ovate scales, to $10 \mathrm{~cm}$ wide but usually 2.5 $5.0 \mathrm{~cm}$ wide, occurring singly or in clusters, usually partly above the ground (Fig. 3). Leaves 2-5, grasslike, suberect. Flowers in or out of leaf. Inflorescences 30 to $150 \mathrm{~cm}$ tall bearing up to 60 flowers (Fig. 2). Flowers typically $2.5 \mathrm{~cm}$ wide (Fig. 1), with sepals and petals dull green with brownish purple netted veins; sepals spreading with lateral sepals held slightly above horizontal; petals pointing forward above the column; lip three lobed with two short lateral lobes green with purple striping and rolled inward to the column to form a short tube, median lobe white marked with rose-pink, elongate extending forward and downward,

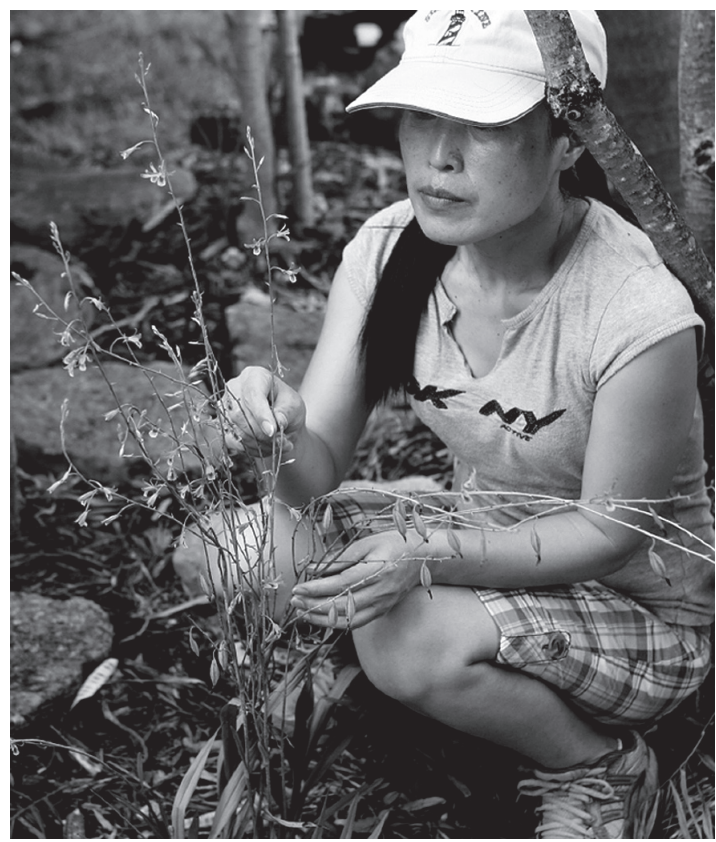

FIGURE 2. Whole flowering plant of the naturalized Eulophia graminea growing in woodchip mulch in South Miami, Florida. Note the capsules.

wavy-crisped along margin, and turning into white and rose papillae; spur at base of lip long, dilated at tip; Fruit a capsule ca. $3 \mathrm{~cm}$ long by $0.8 \mathrm{~cm}$ wide when fully grown (Fig. 4).

Only one other Eulophia species, the native E. alta (L.) Fawc. \& Rendle, occurs in Florida and the United States (Romero-González 2007). Luer (1972) included Eulophia ecristata (Fernald) Ames in "The Native orchids of Florida", but this species is now Pteroglossaspis ecristata (Fernald) Rolfe. These three orchids are readily separated by the symmetry of both the inflorescences and the individual flowers, as well as flower color. Pteroglossaspis ecristata flowers are borne on a raceme and have yellow green petals and sepals converging over the brown purple lip. Eulophia alta flowers are in racemes and are green to purplish (but color can be quite variable), with lateral sepals held erect and spreading at 45 degree angles. E. graminea has green flowers with white lips marked with rose borne on racemes or panicles, with the lateral sepals spread widely and held almost horizontally. Eulophia graminea flowers are also smaller than those of $E$. alta (1.4 to $2.6 \mathrm{~cm}$ vs. 3.5 to $4.5 \mathrm{~cm}$ wide). Although the plants of all three species can be a meter or more in 


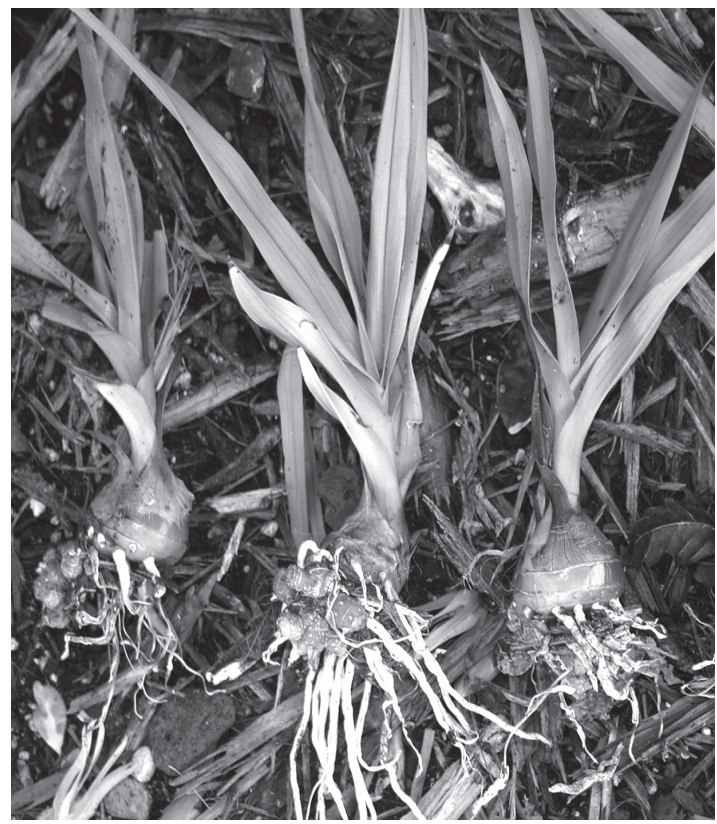

FIGURE 3. Eulophia graminea plants pulled from a mulch bed. Note the distinctive nodes on the large primary pseudobulbs (ca. $3.5 \mathrm{~cm}$ in diameter), the uppermost nodes with paper sheaths, and the proliferation of small pseudobulbs from the bottom and side of the primary pseudobulbs.

height, E. graminea is more slender and has narrower leaves (1-1.5 cm vs. up to $10 \mathrm{~cm}$ wide in E. alta and 3.5 $\mathrm{cm}$ in P. ecristata) than the other two species.

Occurrence in Florida - Eulophia graminea plants were found in small numbers in five different areas of Miami-Dade County in southeastern Florida. The discovery occurred when three flowering plants of an unknown orchid growing in the yard of a neighbor were brought to one of us (SK) during September 2007. We investigated this South Miami yard on October 5 and found 17 bulbs of the orchid growing in woodchip mulch beneath shrubs and small trees. The property owner first observed a large flowering plant in the yard "a year or more earlier." He first observed a single large plant that flowered and produced fruit. Subsequently, he noticed many bulbs of the orchid, prompting him to remove "several dozen." He was alarmed at the proliferation of the plants and suspected that species could be invasive. Our survey of this South Miami neighborhood located bulbs in three other yards within the same block as the reporting neighbor. In the second

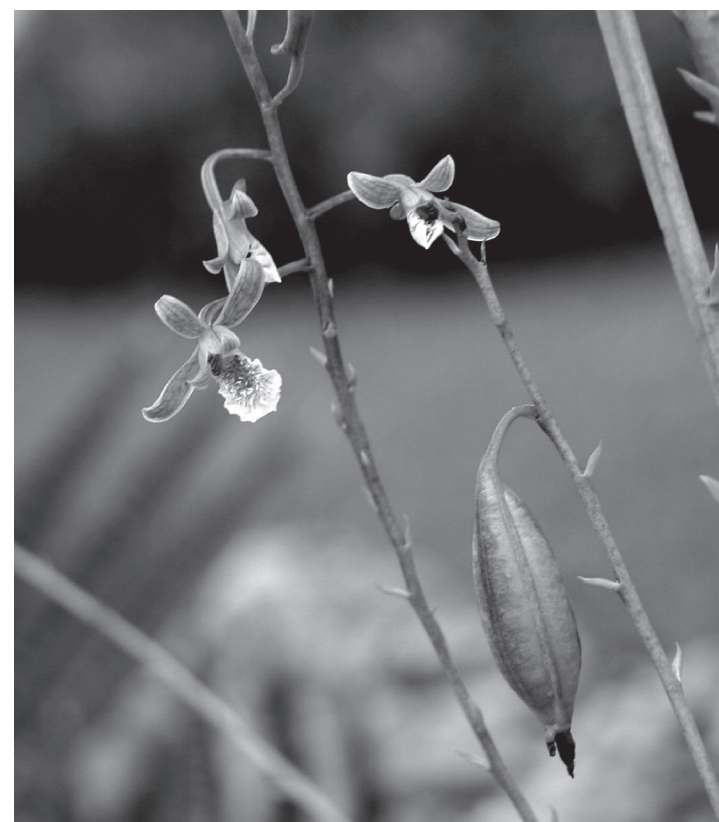

Figure 4. Fruit of Eulophia graminea. The capsules ( $c a$. $3 \mathrm{~cm}$ long $\times 0.8 \mathrm{~cm}$ wide) ripen and dehisce quickly, allowing the spread of seed while plant is still in flower.

yard with the orchid, a single bulb was growing in mulch beneath an avocado tree. The third yard had one plant with three bulbs in mulch beneath a coconut and two other plants in a mulched, partially shaded, flower bed. The fourth yard had four large flowering plants and two other plants with two large non-flowering bulbs. All were growing in mulch in partial shade of palms and other trees, except for one flowering plant in an open mulched bed. The four flowering plants bore tall ( 0.7 to $1.5 \mathrm{~m}$.), slender inflorescences in various stages of flowering and fruiting. On these four plants, the number of inflorescences, open flowers and fruits were as follows: 1) 4 inflorescences, 15 flowers, 8 fruits; 2) 10 inflorescences, 82 flowers, 18 fruit; 3) 1 inflorescence, 15 flowers, no fruit; 4) 1 inflorescence, 15 flowers, no fruit; and an average of 6.5 fruit per plant. This homeowner with the flowering plants was influenced by the reporting neighbor to pull and dispose of bulbs in the garbage, but decided to leave some flowering individuals. He also obtained mulch from the reporting neighbor, which could have contained bulbs or seed of the orchid. Pseudobulb size ranged from 1 to 10 
$\mathrm{cm}$; we also observed extensive vegetative production of small bulbs beneath, or adjacent to, the primary pseudobulbs. The large pseudobulb of one plant, which grew partly beneath a heavy concrete stepping stone, lifted the stone ca. $5 \mathrm{~cm}$ above the mulch, as it grew and expanded. Some large inflorescences had unopened buds on their upper portions and ripe dehiscing fruit on the lower sections. Surveys of parks and mulched areas within approximately one mile of this South Miami occurrence failed to locate additional plants.

The second occurrence of E. graminea was in a residential neighborhood in west Kendall, ca. 8.5 $\mathrm{km}$ southwest of the South Miami population. The brother of the homeowner (with flowering plants at the South Miami site) has a landscape maintenance business, and suggested that we check the yard of a client because he thought that the orchid might occur there. A single tight cluster of pseudobulbs was found in a mulched bed at the house. A survey of this neighborhood resulted in an additional large pseudobulb with leaves growing in mulch in a yard about two blocks to the west of the first house.

The third occurrence of E. graminea was reported to us by a botanist colleague Steve Woodmansee, who found a plant growing in mulch in his yard in eastern Kendall. This site is ca. $2.4 \mathrm{~km}$ west of the South Miami population, and between the South Miami population and the west Kendall occurrence. He first observed the plant in 2006. No flowers were observed until an inflorescence appeared in December, 2007. Flowers opened in mid January, 2008 on a single inflorescence, $0.38 \mathrm{~m}$ tall, and borne on a bulb $4 \mathrm{~cm}$ wide. About 30 flowers were produced but no fruits formed on the plant.

The fourth occurrence of $E$. graminea was reported to us by orchid grower Donald Wallstedt, who discovered a population of the orchid growing in the Little River area of Miami. This site is $19.4 \mathrm{~km}$ north of the South Miami population and $31.1 \mathrm{~km}$ north of the southern most site in western Kendall. Wallstedt first observed the plants during March 2008. The plants were found growing on adjacent vacant lots amidst grass and Bidens pilosa L. on shallow sandy limestone soil scattered with concrete, tile and other debris. The orchids occurred mostly in the open partly sunny central area of the two lots, where houses stood before being torn down during the summer of 2005 (Donald Wilson, pers. comm.). Because the site is due to be developed, Wallstedt removed 40 of the largest flowering plants to save them, planting most in his nearby garden and giving others away. Fifteen of the transplanted plants in pots in his garden had exposed pseudobulbs, and these averaged $5.2 \mathrm{~cm}(\mathrm{sd} .=1.8)$ in diameter. One unusually large plant had a mass of pseudobulbs $35 \mathrm{~cm}$ long by $11.3 \mathrm{~cm}$ wide, and bore 12 inflorescences. During a survey of the Little River Miami naturalization site on April 5, 2008, 29 additional plants including 27 reproductive (flowering and/or fruiting) plants were found. These plants had a mean of $1.26(\mathrm{sd} .=0.447)$ inflorescences ranging from $0.3-0.9 \mathrm{~m}$ tall with a mean height of $0.45 \mathrm{~m}$ (sd. $=0.141$ ). Twenty one plants had a total of 103 open flowers and a mean of $5.38(\mathrm{sd} .=3.38)$ flowers per plant. Twenty seven reproductive plants had a total of 92 fruit on 23 different plants, ranging from 0-9 fruit, and an average of $3.41(\mathrm{sd} .=2.63)$ fruit per plant.

The fifth and last site where Eulophia graminea was detected is in North Miami, which is north of the Little River Miami site, and $24.3 \mathrm{~km}$ north of the South Miami site and $34.9 \mathrm{~km}$ north of the western Kendall site. Ronald Pereira found the plant and directed us to the site where we found a single plant growing in woodchip mulch in a Publix supermarket parking lot island. The inflorescence of the plant was $0.3 \mathrm{~m}$ tall and bore three old and three fresh flowers but no fruit.

Breeding system and pollination - Eulophia graminea flowers have a nectar spur containing nectar. We found the nectar to have $>2 \%$ glucose as indicated by Diastix $\mathrm{R}$ (Bayer) glucose test strips used on three flowers. No fragrance could be detected in single flowers, but we were able to detect fragrance from inflorescences bearing many flowers during the morning. Flower longevity (determined with 15 flowers on two potted plants held inside a screen enclosure to exclude potential pollinators, and tagged the first day they opened and followed until they wilted) was 5-16 days, with a mean longevity of $10.9(\mathrm{sd} .=3.4)$ days. None of these tagged 15 flowers, or the other ca. 15 untagged flowers on these potted plants in the enclosure, set fruit, indicating the orchid is probably not autogamous. Hand pollination treatments with self pollinia resulted in fruit formation in 4/10 flowers, indicating a degree of self-compatibility. All 10 flowers hand pollinated with out-cross pollinia set fruit. 
Flowers on the two flowering plants scored at the South Miami site for pollinia removal on Oct. 14 had no pollinia missing $(0 / 15$ and $0 / 82)$. Two flowers had pollinia partly out of the anthers, and one of these almost touched the stigma. The three flowering plants examined for pollinia removal on Nov. 10 had no missing pollinia in a total of 28 flowers $(0 / 4,0 / 11$, 0/13). Dissections of 20 wilted flowers from the site found two pollinia on the stigmatic surface and pollinia of many other flowers hanging from below the anther cap. One hundred thirteen flowers evaluated on 21 plants at the Little River Miami site on April 5, 2008, had an average pollinia removal of $24.3 \%(\mathrm{sd} .=25.6)$. Three potted plants with 86 flowers exposed in a garden in Ft. Lauderdale failed to produce fruit, but two fruits were produced on a potted plant exposed in a garden in Homestead that had ca. 15 flowers. The percent fruit set of the flowers on the 13 inflorescences on the three plants growing at the South Miami site was: $4.9 \%$ (4 fruit/81 flowers), $2.3 \%$ (3 fruit/133 flowers), and $6.0 \%$ (4 fruit/65 flowers), and a mean of $4.45 \%$ (sd. $=1.99$ ). The mean fruit set for 27 reproductive plants growing at the Little River Miami site was $9.18 \%(\mathrm{sd} .=7.14)$ per plant.

Aside from ants (Brachymyrmex obscurior Forel), encountered in some flowers at the South Miami site, no flower visitors were observed during limited timed watches (in periods between 8:45am and 4:20pm on Oct. 14, Nov. 4 and Nov. 10, 2007, Feb. 2, and April 5, 2008) totaling 390 minutes on 188 flowers on 12 plants.

Possible Introduction Routes - The means by which the orchid entered Florida and the U.S. is unknown. Although the flowers are not showy compared to most cultivated orchids, there is some cultivation of Eulophia graminea and commerce in the plants. Directions for its cultivation in Singapore are given by Tan and Sin (1993), but with the comment that the orchid is not very attractive. Several current postings on eBay (Feb.-March 2008) offered plants for sale. A Thai orchid grower (Kasorn Orchids in Bangkok) offered flasks containing 30-40 plantlets for \$12/flask. Another Thai grower (LONUN Thailand in Bankok) listed packets of five E. graminea bulbs for \$8, and someone in Scotland offered bulbs for sale. There was a website posting on the Terrestrial Orchid forum from a man in Germany requesting advice for the cultivation of E. graminea bulbs that he acquired from Thailand. A garden website had a posting from someone in Singapore (part of the native range), offering to trade an E. graminea capsule (www. Gardenbanter.co.uk). Also of interest, because of the orchid's naturalization in Australia, was the selling of the E. graminea by the Australian eBay Australian store, by another Thai seller (Thai Tropicals), which currently offers 10 bulbs for ca. 2.14 Australian dollars.

Another possible introduction route could have been the importation of bulk raw materials from the orchid's native region in Asia containing its seed or bulbs. The bulk material that seemed to have the potential to carry the orchid material is woodchip component of the "Logs and woodchips" import category, and these were imported to the U.S. from Eulophia graminea's native range (Malaysia, Indonesia, Singapore, China, Taiwan) (http://www.fas.usda.gov/scriptsw/bico/bico. asp?Entry=lout\&doc=967). It is not known, however, what portion of this category woodchips represents, if the woodchips are treated prior to export or after import in a manner that would kill orchid propagules, or where these imported woodchips end up in the United States. No evidence for imported mulch was found except possibly the woodchips if used for mulch.

\section{Discussion}

Occurrence - It is highly likely that other undetected plants occur in Miami-Dade County and perhaps beyond. All five Eulophia graminea occurrences or populations were found with the assistance of other people. Our surveys to try to find new occurrences have been limited, and we have not investigated some of our local habitats of the same types the orchid occupies in its native area, such as beach, coastal grasslands, and secondary forest.

Possible routes of introduction - Although no evidence for cultivation or commerce of the orchid in the U.S. was discovered, we found that the orchid is cultivated overseas and is available as seed, bulbs, and plantlets in flasks by web-based businesses and private individuals. This suggests that importation to Florida could easily occur, although CITES restrictions on orchid importation might restrain and limit its legal importation. Butboth legal and illegal importation could 
have occurred. The availability of Eulophia graminea is coupled with considerable enthusiasm for orchid growing in southern Florida. The American Orchid Society alone has ca. 25 affiliated chapters in the three highly populated counties (Broward, Miami-Dade, and Palm Beach) in southeastern Florida. The importation of bulk materials from the native area, which could introduce E. graminea seed or pseudobulbs, is another possible introduction route, but less plausible than purposeful importation for horticulture.

Breeding System and Pollination - Although we determined that Eulophia graminea needs a pollinator for pollination, we did not identify the pollinator(s). Fruit set was observed at the South Miami and Little River Miami naturalization sites, and in an exposed potted plant in Homestead. No fruit was seen in the flowering plants at the east Kendall and North Miami naturalization sites, or potted plants exposed in Ft. Lauderdale in Broward County, just to the north of Miami-Dade County. At the South Miami site, pollinia removal was not observed during the two scoring periods during October and November, but a low level of fruit was present during and after those assessments; with a $4.5 \%$ fruit set detected after flowering finished. At the Little River Miami site, pollinia removal was documented (with a mean of $24 \%$ ), and a mean fruit set was $9 \%$. Perhaps the greater number of flowering plants at the Little River Miami site, ca. 70 compared to 4 at the South Miami site, may have resulted in both more flower visitation and increased chances for reproductive success. In addition, the much greater presence of flowering weeds such as B. pilosa at the Little River Miami site could have also increased pollinator presence and activity. In other studies of tropical orchid pollination (Tremblay et al. 2005), pollinia removal rates were usually higher than fruit set rates. Pollinia removal rates were, however, higher in deceptive tropical orchids, but not in rewarding tropical orchids (Tremblay et al. 2005) such as E. graminea. Because our visits and observation periods were few, we could have missed the activity periods of pollinators responsible for the fruit set. It might also be possible, despite the absence of fruit set in enclosed plants or in exposed plants in Ft Lauderdale, that some low level autogamy occurs. The presence of nectar and fragrance in the daytime, the prominent lip with coloration contrasting coloration, papillae, and a gullet (formed by the lateral lobes of the lip) suggest pollination by bees. More observations are needed to detect the pollinator(s) and additional treatments to determine whether a limited amount autogamy might be possible in plants in the field.

Potential to persist - The underground (or partially underground) pseudobulbs, particularly those buried in mulch, probably provide a means to survive the dry season and drought. Mulch is widely utilized in southern Florida, in part, to conserve moisture for garden plantings. Part of the plant's native range (South and Southeast Asia) experiences an intense dry season with higher temperatures than occur in Florida's dry season. During these times the leaves dry and the plant become dormant (Tan \& Sin 1993). The pseudobulb, particularly those that are underground, may be better able to survive the rare freeze events southern Florida experiences, and may allow it to persist farther north in Florida, and perhaps beyond.

Potential to spread - Eulophia graminea has capsules which ripen and dehisce quickly, suggesting that its spread by seed is likely. The occurrence of multiple plants in relatively small areas of three neighborhoods also suggests local spread by air-borne seed. The occurrence in five separated areas of Miami-Dade County might also be due to wind blown seed, but spread by the movement of seeds or pseudobulbs in mulch is also possible. We know that mulch was shared from the first yard in the South Miami (where the orchid was found) with another neighbor where we also found the plants. The ability of the orchid to persist as dormant pseudobulbs can probably facilitate their survival during movement with mulch.

Eulophia graminea occurs beyond the tropics in some parts of its native range. The northeast part of its range in Okinawa (Garay \& Sweet 1974) is just above $26^{\circ} \mathrm{N}$, which is the same latitude as Miami-Dade County. The orchid lives in the Himalayas between 900-1000 $\mathrm{m}$ in Nepal and Sikkim) (Singh 2001). Nepal lies between $26-32^{\circ} \mathrm{N}$, but areas at or below $1000 \mathrm{~m}$ lie in the lower latitudes of the country. Sikkim lies between 27 and $28^{\circ} \mathrm{N}$. The orchid's occurrence in Kashmir (Renz 1984), an elevated region, whose southern border lies above $32^{\circ} \mathrm{N}$, is the region with the most temperate climate in the plant's native range. 
One inland Chinese location for the plant is in Anhui province is ca. $32^{\circ} \mathrm{N}$ (Chinese distribution map for the species, Tropicos, Missouri Botanical Garden), but this locality is unconfirmed. The occurrence of the $E$. graminea at higher latitudes and higher elevations than the $26^{\circ} \mathrm{N}$ and near sea level occurrence in southern Florida, suggests that the plant could survive well north of its current area of naturalization. If the orchid is able to live at $32^{\circ} \mathrm{N}$ in the southeastern U.S., it could occur from southern Georgia to eastern Texas. The source area of the plants that have naturalized in southern Florida is, however, unknown, and the naturalized plants may not necessarily have the cold tolerance of plants occurring in the more northern parts of the native range. The large native geographic range, including its occurrence on isolated islands, suggests an ability to disperse and to spread widely. Eulophia graminea was one of the first orchids to colonize Krakatau Islands after the 1883 massive eruption, being detected in 1908 (Partomihardjo 2003).

This combination of the orchid's more northern occurrence in its native range, its ability to seed quickly and disperse over great distances, vegetative proliferation of its pseudobulbs, and terrestrial pseudobulbs which can be dormant, all suggest that Eulophia graminea will probably spread in Florida and possibly north of Florida to Georgia the Carolinas. The orchid could spread to the West Indies by windborne seed. It could also be moved accidentally (as pseudobulbs or seed) as contaminants of horticultural potted plants exported from Florida to warmer parts of the US and to the West Indies. Eulophia graminea could also be moved intentionally by people for cultivation.

We found the orchid growing in mulch at four of the five sites in southern Florida; it has also naturalized in mulch in Australia. All of the detected plants in mulch were found in woodchip mulch, although the roots of some plants may have been growing into soil beneath the mulch. Mulch might have the mycorrhizae needed by the orchid for seed germination and establishment. Mulch harbors many fungi, and alien fungi have been first detected in ornamental woodchip mulch (Shaw et al. 2004). The orchid is reported to have a wide tolerance of environmental conditions (Tan \& Sin 1993), and its occurrence on sandy beaches, grasslands, and other shrubby, open areas, and secondary forests in its native area, indicate that it could colonize these habitat types in Florida. The habitats the orchid colonizes will probably depend on whether suitable mycorrhizae occur in them.

Orchid naturalization - Only 11 species of orchids are naturalized in Florida (Wunderlin and Hansen 2004). With the addition of Eulophia graminea, this is around $10 \%$ of the total orchid species in the state. This indicates that naturalization of orchids in Florida occurs less frequently than either other flowering plants (ca. 33\% naturalization) or ferns (ca. 33\%) (Pemberton 2003). Lower naturalization rates in orchids appears to be a general occurrence (Daehler 1998). Eleven of 12 of the orchids naturalized in Florida are terrestrial species, suggesting that terrestrial species may naturalize more easily than epiphytes. This is noteworthy because epiphytic orchids dominate horticulture and home cultivation in Florida, although a couple of terrestrial species, Spathoglottis plicata Blume and Phaius tancarvilleae (Banks ex L'Hér.) Blume, are commonly sold. Both orchids are naturalized in Florida to a limited extent (Wunderlin \& Hansen 2008). The lack of specialist pollinators and appropriate mycorrhizae are thought to limit orchid naturalization (Daehler 1998). Terrestrial environments, particularly mulch, may provide more potential mycorrhizae needed by orchid seed to germinate than do the arboreal habitats of epiphytic orchids. An invasive orchid, Disa bracteata Sw., and a weedy native orchid, Microtis media R.Br., in Australia form associations with a greater array of mycorrhizal fungi of more world-wide occurrence than do nonweedy native orchids (Bonnardeaux et al. 2007).

While the breeding system of colonizing orchids may be diverse (Sun 1997), the only wide-spread naturalized orchids in Florida, Oeceoclades maculata (Lindl.) Lindl. and Zeuxine strateumatica (L.) Schltr.), are thought to be autogamous (Sun 1997, GonzálezDíaz \& Ackerman 1988). This supports, in part, the idea that pollination limitation may be a barrier to orchid naturalization. The recent naturalization of two tropical bees in southern Florida, an orchid bee (Pemberton \& Wheeler 2006), and an oil-collecting bee (Pemberton \& Liu 2008), may reduce this pollinator limitation and both promote some already naturalized orchids and facilitate the naturalization of some ornamental 
orchids. The orchid bee, Euglossa viridissima Friese, visits many different ornamental orchids (Pemberton 2007a), and is pollinating and causing considerable fruit set in Guarianthe skinneri (Bateman) Dressler \& W.E. Higgins (Pemberton 2007b). The oilcollecting bee, Centris nitida Smith, is pollinating and inducing fruit set in the ornamental Oncidium sphacelatum Lindl. (Pemberton, in press), and is the only known pollinator of the invasive cowhorn orchid, Cyrtopodium polyphyllum (Vell.) Pabst ex F. Barrios, (Liu and Pemberton, unpubl. data). It is doubtful that either of these naturalized bees visits the flowers of Eulophia graminea because they are quite unlike the flowers used by them.

Eulophia graminea is probably destined to be a permanent part of Florida's flora, given its multi-site and relatively wide occurrence during the early phase of its colonization, as well as its ability to produce ample fruit and persist during the dry season via its dormant pseudobulbs. It will be interesting to observe the extent of this alien orchid's colonization and spread in the New World and to try to understand the reasons for its successful naturalization.

Acknowledgements. Surangraj Indhamusika, of the Queen Sirikit Botanical Garden in Chiang Mai Thailand, confirmed the identity of Eulophia graminea, Stig Dalstrom of the Orchid Identification Center at Marie Selby Gardens and Mario Blanco of University of Florida assisted in the identification of the orchid. Harvey Bernstein first brought plants of an unknown orchid to SK and shared his observations of the plants with us. Tom Dickinson suggested the possible occurrence of the orchid at the west Kendal site. Steve Woodmansee shared his discovery of a plant in east Kendall site. Donald Wallstedt and Ronald Pereira shared their discoveries of plants at Little River Miami and North Miami sites, respectively. We appreciate the Harvey Bernstein and the Gordon Lee Dickinson families for allowing us to study E. graminea in their yards, and realtor Donald Wilson for permission to study the plants at the Little River Miami site and for information about the site.

\section{Literature Cited}

Bonnardeaux, Y, M. Brundrett, A. Batty, K. Dixon, J. Koch \& K. Sivasithamparam. 2007. Diversity of mycorrhizal fungi of terrestrial orchids: compatibility webs, brief encounters, lasting relationships, and alien invasions. Mycolog. Res. 111: 51-61.
Daehler, C.C. 1998. The taxonomic distribution of invasive plants: ecological insights and comparison to agricultural weeds. Biol. Conserv. 84: 167-180.

Garay, L.A. \& H.R. Sweet. 1974. Orchids of southern Ryuku Islands. Harvard Univ. Press.

González-Díaz, N. \& J.D. Ackerman.1988. Pollination and seed production in the orchid Oeceoclades maculata. Lindleyana 3:150-155.

GRIN (Germplasm Resources Information Network) Taxonomy of plants. 2008. http://www.ars-grin.gov/ cgi-bin/npgs/html/taxgenform.pl (last accessed March, 2008)

Hussey, B.M.J. \& S.G. Lloyd. 2002. Western weeds, additions, deletions and name changes. Western Australian Government. http://members.iinet.net.au/ weeds/ww_ update.pdf (last accessed February, 2008).

Keng, H., S.C. Chin \& H.T.W. Tan. 1998. The concise floral of Singapore, Vol. II Monocots. National University Singapore Press. 234 p.

Luer, C. 1972. The native orchids of Florida. The New York Botanical Garden, New York.

Macrae, C. 2002. New Weed Found in Darwin. Department of Business, Industry and Resource Development, Primary Industry and Fisheries, Northern Territory Government, Australia. (last accessed 31 January 2008)

Partomihardjo, T. 2003. Colonisation of orchids on the Krakatau Islands. Telopea 10: 299-310.

Pemberton, R.W. 2003. The common staghorn fern, Platycerium bifurcatum, naturalizes in southern Florida. Amer. Fern J. 93: 204-207.

Pemberton, R.W. \& G.S. Wheeler. 2006. Orchid bees don't need orchids, evidence from the naturalization of an orchid bee in Florida. Ecology 87: 1995-2001.

Pemberton, R.W. 2007a. An orchid bee naturalizes in Florida; implications for orchids and other plants. Orchids 76: 446-448.

Pemberton, R.W. 2007b. Invasive orchid bee, Euglossa viridissima, pollinates the ornamental orchid (Guarianthe skinneri) in Florida. Lankesteriana 7: 461-468.

Pemberton, R.W. \& H. Liu. 2008. The naturalization of an oil collecting bee Centris nitida in Florida and the eastern United States, with notes on the Centris species native to Florida. Florida Entomol. 91: 101-109.

Pemberton, R.W. in press. Pollination of the ornamental Oncidium sphacelatum by the naturalized oil-collecting bee (Centris nitida) in Florida. Selbyana.

PIER (Pacific Island Ecosystems at Risk project). 2008. http://www.hear.org/pier/prospective.htm (last accessed in March 2008).

Renz, J. 1984. Orchidaceae. Pp. 1-63 in: E. Nasir \& S.I. Ali (eds.), Flora of Pakistan 164. PanGraphics Ltd., Islamabad.

LANKESTERIANA 8(1), abril 2008. (C) Universidad de Costa Rica, 2008 
Romero-González, G.A. 2007. Eulophia, In: RomeroGonzález, G.A., G.C. Fernández-Concha, R.L. Dressler, L.K. Magrath \& G.W. Argus. 2007. Orchidaceae, Flora of North America Vol. 26, p. 640. Online version http:// www.efloras.org (last accessed Feb., 2008)

Shaw, P.J.A., J. Butlin \& G. Kibby. 2004. Fungi of ornamental woodchips in Surrey. Mycologist 18: 12-15.

Singh, A.P. 2001. Flowering plants of Nepal (Phanerogams). Bulletin of Plant Resources 18: 1-399. (Godavary, Nepal).

Su, H.-J. 2000. Orchidaceae. In: The Editorial Committee of the Flora of Taiwan Flora of Taiwan (http://www. efloras.org/florataxon.aspx?flora id=100\&taxon $\mathrm{id}=242321178$ ).
Sun M. 1997. Genetic diversity in three colonizing orchids with contrasting mating systems. Amer. J. Bot. 84: 224232.

Tan, H.T.W. \& H.C. Sin. 1993. A guide to the orchids of Singapore. Singapore Science Center, Singapore.

Tremblay, R.J., J.D. Akerman, J.K. Zimmerman \& R.N. Calvo. Variation in sexual reproduction in orchids and its evolutionary consequences: a spasmodic journey to diversification. Biol. J. Linn. Soc. 84: 1-54.

Wunderlin, R. P., and B. F. Hansen. 2004. Atlas of Florida vascular plants (http://www.plantatlas.usf.edu/) (last accessed March, 2008). 